\title{
PARTICLEBOARD PRODUCTION WITH RESIDUES FROM MECHANICAL PROCESSING OF AMAZONIAN WOODS ${ }^{1}$
}

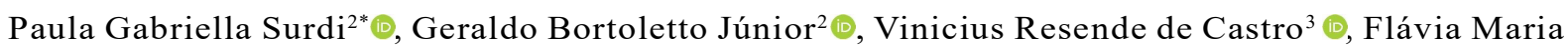

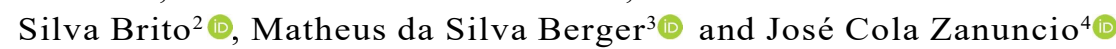

\footnotetext{
${ }^{1}$ Received on 16.04.2018 accepted for publication on 20.11.2018.

${ }^{2}$ Universidade de São Paulo, Escola Superior de Agricultura Luiz de Queiroz, Piracicaba, SP-Brasil. E-mail: <paulasurdi@gmail.com>, <gbjunior@usp.br> and <faengflorestal@gmail.com>.

${ }^{3}$ Universidade Federal de Viçosa, Departamento de Engenharia Florestal, Viçosa, MG-Brasil. E-mail: < vinicius.castro@ufv.br> and $<$ matheus.berger@ufv.br>.

${ }^{4}$ Universidade Federal de Viçosa, Departamento de Entomologia, Viçosa, MG-Brasil. E-mail: <zanuncio@ufv.br>.

*Corresponding author.
}

\begin{abstract}
The lack of use of the residues generated by the mechanical processing of wood and their inadequate disposal are challenges for the timber industry. They have potential for products with higher value. The purpose of this research was to evaluate the use of residues generated by the mechanical processing of Amazonian woods Caryocar villosum, Hymenolobium excelsum, Mezilaurus lindaviana, Erisma uncinatum, Tachigali myrmecophyla and Qualea paraensis in the high-density particleboard production. The panels produced had nominal density of $850 \mathrm{~kg} \cdot \mathrm{m}^{-3}$, nominal thickness of $15.7 \mathrm{~mm}$ and $8 \%$ of phenol formaldehyde adhesive. The physical-mechanical properties of the panels produced from each species and with a mixture of all of them in equal parts were evaluated. The specimens from the panels were prepared for physical tests (apparent density, moisture content, water absorption and thickness swelling) and mechanical tests (static bending - modulus of elasticity and modulus of rupture, and internal bond) according to the standard ABNT NBR 14810-3. The mechanical properties of the particleboards manufactured with the C. villosum, H. excelsum and T. myrmecophyla residues were generally superior than those of the other species and met one or more of the minimum requirements indicated by the ANSI A208.1 standard for (H-1 classification) and for floors production (PBU classification).
\end{abstract}

Keywords: Tropical wood; Wood panels; Physical-mechanical properties.

\section{PRODUÇÃO DE PAINÉIS AGLOMERADOS COM RESÍDUOS DO PROCESSAMENTO MECÂNICO DE MADEIRAS AMAZÔNICAS}

\begin{abstract}
RESUMO - A falta de aproveitamento dos resíduos gerados pelo processamento mecânico da madeira e seu descarte inadequado são desafios para a indústria madeireira. Esses poderiam ser utilizados em produtos de maior valor agregado. O objetivo deste trabalho foi avaliar a utilização de resíduos gerados pelo processamento mecânico das madeiras amazônicas Caryocar villosum, Hymenolobium excelsum, Mezilaurus itauba, Erisma uncinatum, Tachigali myrmecophyla e Qualea paraensis na produção de painéis aglomerados de alta densidade. Os painéis foram produzidos com massa específica nominal de $850 \mathrm{~kg} \cdot \mathrm{m}^{-3}$, espessura nominal de $15,7 \mathrm{mme}$ adesivo fenol-formaldeído na proporção de 8\%. As propriedades fisico-mecânicas dos painéis produzidos a partir de cada espécie e de uma mistura entre todas elas em partes iguais foram avaliadas em sete tratamentos. Corposde-prova, retirados dos painéis produzidos, foram confeccionados para ensaios fisicos (massa específica, teor de umidade, absorção de água e inchamento em espessura) e mecânicos (flexão estática - MoR e MoE, e ligação interna) de acordo com a norma ABNT NBR 14810-3. As propriedades mecânicas dos painéis aglomerados, manufaturados com os resíduos de C. villosum, H. excelsum e T. myrmecophyla foram, de maneira geral, superiores às das demais espécies e atenderam um ou mais dos requisitos mínimos indicados pela norma ANSI A208.1 para painéis de alta densidade (classificação H-1) e destinados a produção de pisos (classificação PBU).
\end{abstract}

Palavras-Chave: Madeiras tropicais; Painéis de madeira; Propriedades físico-mecânicas. 


\section{INTRODUCTION}

In 2016, Brazil produced 2.73 million $\mathrm{m}^{3}$ of tropical sawn timber with the highest production in Latin America (ITTO, 2016). This position presents challenges related to illegal occupation and logging in the Amazon. Other problems include the large generation of residues produced in the mechanical processing of wood. These losses relate to low labor qualification, process automation, and different species wood processed (Melo et al., 2012; Nolasco and Uliana, 2014).

The utilization of Amazonian wood residues is low with inappropriate disposal, but they have potential for products with higher value as particleboards. The high availability of wood residues in the Amazon region may be an alternative for panel industries, including the engineered floors produced with wood panels in the base or substrate. This application requires panels with high apparent density and particles of smaller size for a better surface finish with moisture resistant adhesive (Iwakiri et al., 2005).

The panel quality depends on wood factors, such as species, extractives and basic density, besides those related to processing. Wood properties affect the bonding formation with, generally, greater difficulties for hardwoods (Marra, 1992). The wood basic density is also a limiting factor, since the industry usually uses wood with densities lower than $550 \mathrm{~kg} . \mathrm{m}^{-3}$ (Maloney, 1993). The use of species mixture with increasing utilization of tropical wood could allow reaching the properties required for particleboards production.

The Amazonian wood workability presents difficulties and the quality and the potential of its application for specific wood products needs to be better studied, even with some studies developed for the these wood use to produce particleboards (Iwakiri et al., 2010; 2012; Trianoski et al., 2015).

The raw material used in the timber industry has increased and, consequently, the waste from Amazonian plants. The objective was to evaluate the high-density particleboards for semi-structural application as engineered floors produced with residues generated by the mechanical processing of the tropical woods Caryocar villosum (Aubl.) Pers., Hymenolobium excelsum Ducke, Mezilaurus itauba (Meisn.) Taub. Ex Mez, Erisma uncinatum Warm., Tachigali myrmecophyla Ducke and Qualea paraensis Ducke.

Revista Árvore. 2019;43(1):e430102

\section{MATERIALAND METHODS}

\subsection{Experimental Design}

The particleboards of six species and a mixture of all of them in equal parts represented the seven (7) treatments in a completely randomized experimental design. Each treatment had three (3) panels with a nominal specific mass of $850 \mathrm{~kg} \cdot \mathrm{m}^{-3}$ and nominal thickness of $15.7 \mathrm{~mm}$.

\subsection{Particleboards production}

The wood residues of Caryocar villosum, Hymenolobium excelsum, Mezilaurus itauba, Erisma uncinatum, Tachigali myrmecophyla e Qualea paraensis were transformed into chips by a forest chipper powered by a tractor power outlet. Wood particles were produced by processing the chips in a Willey knife mill using a $4 \mathrm{~mm}$ sieve opening. The particles were dried in a laboratory forced-air circulation oven at a temperature of $90{ }^{\circ} \mathrm{C}$. Drying was concluded when the particles reached moisture content between 3 and 5\%.

The entire material, including the fines (particles that passed through the $0.50 \mathrm{~mm}$ sieve and were retained in the vibratory machine collector), was used to the production of the panels.

The adhesive phenol-formaldehyde was applied to the particles with a solids content of $52.32 \%$, gel time at 121 ${ }^{\circ} \mathrm{C}$ of 8.19 minutes, and viscosity of $640 \mathrm{cP}$ at $25^{\circ} \mathrm{C}$, with $8 \%$ of resin solids based on the dry mass of the particles. Liquid paraffin at $1 \%$ solids was also applied to the particles in all treatments on the same basis as the adhesive.

The particles impregnated with adhesive and paraffin were manually placed into a mat-forming wooden box (400 $\mathrm{mm}$ for the inner edge and $200 \mathrm{~mm}$ height).

The particulate mat was placed in a hydraulic press for hot pressing. The maximum pressure used during the panels pressing was $35 \mathrm{kgf} / \mathrm{cm}^{2}$ at a temperature of 180 ${ }^{\circ} \mathrm{C}$ and total time of 10 minutes using $15.7 \mathrm{~mm}$ thickness separators.

The particleboards, after cooling, were conditioned in an air-conditioned room with controlled temperature and relative humidity at $22 \pm 2{ }^{\circ} \mathrm{C}$ and $65 \pm 5 \%$, respectively, until constant mass, indicating that they reached the equilibrium moisture with the environment.

The apparent density, moisture content, water absorption and thickness swelling after 2 and 24 hours

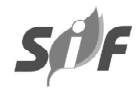


of immersion, modulus of rupture (MoR) and modulus of elasticity (MoE) to static bending, and resistance to perpendicular traction (internal bonding) were the panels properties evaluated in physical-mechanical tests. Specimen dimensions, test realization and property value calculations complied with the requirements of standard NBR 14810-3 (ABNT, 2006).

The wood basic density was determined by the immersion method according to NBR 11941 (ABNT, 2003) and the compression ratio by dividing the apparent density value of the panel by the wood basic density.

\subsection{Statistical analysis}

The data of the parameters evaluated were submitted to variance analysis and Tukey test at $5 \%$ of probability of error, to identify the means that differed from each other. The analysis were done with the SISVAR program.

The mean property values were obtained per treatment and compared with the minimum values specified by standard ANSI A208.1 (CPA, 2009) for high-density particleboards (H-1 classification) and particleboards for floor underlying (PBU classification).

\section{RESULTS}

\subsection{Basic density of woods and compression ratio of panels}

The wood basic density and panel compression ratio ranged from 503.75 to $759.53 \mathrm{~kg} \cdot \mathrm{m}^{-3}$ and from 1.1 to 1.7 , respectively (Table 1 ).

\subsection{Physical properties of panels}

The apparent density varied between treatments with mean values of 819.01 to $834.10 \mathrm{~kg} \cdot \mathrm{m}^{-3}$ (Table 2).

The panel thickness varied from 15.68 to 15.99 $\mathrm{mm}$ (Table 2) close to the separator thickness (15.7 $\mathrm{mm}$ ) with lower value for the Mezilaurus itauba than that of Hymenolobium excelsum and Erisma uncinatum wood.

The panel moisture content ranged from 8.5 to $10.2 \%$ (Table 2), with lower values for the Hymenolobium excelsum and Mezilaurus itauba and the mixture of all species wood.

The WA2 $\mathrm{h}$ and WA24h of the particleboards differed between treatments with values from $8.24 \%$ to $37.80 \%$ and $20.26 \%$ to $53.79 \%$, respectively (Table 2 ). The water
Table 1 - Basic density of woods and compression ratio of particleboards.

Tabela 1-Densidade básica das madeiras e razão de compactação dos painéis.

\begin{tabular}{lccc}
\hline \multirow{2}{*}{ Species } & \multicolumn{2}{c}{ Basic density } & \multicolumn{2}{c}{ Compression ratio } \\
\cline { 2 - 4 } & $\left(\mathrm{kg} . \mathrm{m}^{-3}\right)$ & Nominal & Effective \\
\hline Caryocar villosum & $659.73 \pm 8.58$ & 1.3 & 1.3 \\
Hymenolobium & $576.12 \pm 3.64$ & 1.5 & 1.4 \\
excelsum & & & \\
Mezilaurus itauba & $680.71 \pm 8.74$ & 1.2 & 1.2 \\
Erisma uncinatum & $503.75 \pm 5.81$ & 1.7 & 1.6 \\
Tachigali & $556.94 \pm 12.28$ & 1.5 & 1.5 \\
myrmecophyla & & & \\
Qualea paraensis & $759.53 \pm 6.73$ & 1.1 & 1.1 \\
Mixture & $624.05 \pm 7.65$ & 1.4 & 1.6 \\
\hline
\end{tabular}

absorption of the panels produced with Hymenolobium excelsum and Tachigali myrmecophyla was higher than those of the other treatments.

The TS2h of the panels of Tachigali myrmecophyla was higher than those of the other treatments (Table 2). The TS24h of the Tachigali myrmecophyla, Hymenolobium excelsum, Erisma uncinatum and those with all wood residues was higher than the other panels.

\subsection{Mechanical properties of panels}

The MoR values to the static bending of the particleboards (Table 3) with Caryocar villosum, Hymenolobium excelsum and Tachigali myrmecophyla was higher than those of the other treatments.

The MoE (Table 3) of the panels with Caryocar villosum residues was similar to those with Hymenolobium excelsum, Mezilaurus itauba and Tachigali myrmecophyla residues.

The panel internal bonding with Hymenolobium excelsum and Tachigali myrmecophyla residues was better than those of the other treatments (Table 3). The internal bonding values of the panels with Mezilaurus itauba, Erisma uncinatum, Qualea paraensis and the mixture were similar.

\section{DISCUSSION}

Woods analyzed in the present study and their mixture can be classified as medium density, except Qualea paraensis as heavy wood. This classification is based on the range limits of $\leq 500 \mathrm{~kg} \cdot \mathrm{m}^{-3}, 500-720$ $\mathrm{kg} \cdot \mathrm{m}^{-3}$ and $\geq 720 \mathrm{~kg} \cdot \mathrm{m}^{-3}$, respectively, for light, medium and heavy Brazilian Amazon (Melo et al., 1992). 
Table 2 - Apparent density (AD), thickness, moisture content (MC), water absorption (WA) and thickness swelling (TS) of particleboards produced with the species (SP) Caryocar villosum (CV), Hymenolobium excelsum (HE), Mezilaurus itauba (MI), Erisma uncinatum (EU), Tachigali myrmecophyla (TM), Qualea paraensis (QP) and a mixture of these woods (MX).

Tabela 2 - Massa especifica (ME), espessura, teor de umidade (TU), absorção de água (AA) e inchamento em espessura (IE) dos painéis produzidos com as espécies (SP) Caryocar villosum (CV), Hymenolobium excelsum (HE), Mezilaurus itauba (MI), Erisma uncinatum (EU), Tachigali myrmecophyla (TM), Qualea paraensis (QP) e mistura (MX).

\begin{tabular}{lccccccc}
\hline SP & AD & Thickness & MC & WA2h & WA24h & TS2h & TS24h \\
\cline { 2 - 7 } & kg.m ${ }^{-3}$ & $\mathrm{~mm}$ & & & $\%$ & & \\
CV & $832.13 \pm 20.44 \mathrm{a}$ & $15.85 \pm 0.18 \mathrm{ab}$ & $9.5 \pm 0.15 \mathrm{bcd}$ & $16.51 \pm 0.58 \mathrm{~b}$ & $36.87 \pm 1.76 \mathrm{c}$ & $4.84 \pm 0.27 \mathrm{a}$ & $10.80 \pm 0.17 \mathrm{a}$ \\
$\mathrm{HE}$ & $819.01 \pm 9.47 \mathrm{a}$ & $15.99 \pm 0.05 \mathrm{~b}$ & $8.5 \pm 0.29 \mathrm{a}$ & $34.31 \pm 4.56 \mathrm{c}$ & $50.27 \pm 1.15 \mathrm{~d}$ & $8.00 \pm 1.13 \mathrm{~b}$ & $12.94 \pm 0.41 \mathrm{ab}$ \\
$\mathrm{MI}$ & $824.98 \pm 6.93 \mathrm{a}$ & $15.68 \pm 0.04 \mathrm{a}$ & $8.7 \pm 0.31 \mathrm{ab}$ & $15.83 \pm 0.85 \mathrm{ab}$ & $32.18 \pm 1.75 \mathrm{bc}$ & $4.45 \pm 0.61 \mathrm{a}$ & $9.32 \pm 1.27 \mathrm{a}$ \\
$\mathrm{EU}$ & $821.81 \pm 8.84 \mathrm{a}$ & $15.98 \pm 0.19 \mathrm{~b}$ & $10.2 \pm 0.19 \mathrm{~d}$ & $11.59 \pm 2.77 \mathrm{ab}$ & $26.84 \pm 3.90 \mathrm{~b}$ & $5.32 \pm 1.95 \mathrm{ab}$ & $13.48 \pm 4.11 \mathrm{ab}$ \\
TM & $828.16 \pm 6.59 \mathrm{a}$ & $15.92 \pm 0.03 \mathrm{ab}$ & $9.6 \pm 0.36 \mathrm{~cd}$ & $37.80 \pm 4.37 \mathrm{c}$ & $53.79 \pm 1.31 \mathrm{~d}$ & $11.54 \pm 1.05 \mathrm{c}$ & $15.78 \pm 0.41 \mathrm{~b}$ \\
QP & $834.10 \pm 11.22 \mathrm{a}$ & $15.93 \pm 0.02 \mathrm{ab}$ & $10.0 \pm 0.47 \mathrm{~cd}$ & $8.24 \pm 1.08 \mathrm{a}$ & $20.26 \pm 0.97 \mathrm{a}$ & $4.84 \pm 0.37 \mathrm{a}$ & $9.99 \pm 0.57 \mathrm{a}$ \\
MX & $822.09 \pm 8.13 \mathrm{a}$ & $15.87 \pm 0.04 \mathrm{ab}$ & $9.3 \pm 0.13 \mathrm{abc}$ & $14.12 \pm 3.14 \mathrm{ab}$ & $32.74 \pm 2.00 \mathrm{c}$ & $5.24 \pm 0.38 \mathrm{ab}$ & $11.76 \pm 0.49 \mathrm{ab}$ \\
\hline
\end{tabular}

Means followed by the same letter per column do not differ by the Tukey test $(\alpha=0.05)$.

The effective compression ratio of the panels was higher than 1.3, except for those with the Mezilaurus itauba and Qualea paraensis. This value is the minimum for a necessary compaction of the particulate mat, i.e. a minimum condition in which it is possible to ensure that there is sufficient contact area between particles during the pressing operation in order to obtain a good bonding (Maloney, 1993).

All the mean values of effective apparent density of the wood studied was lower than the planned nominal one $\left(850 \mathrm{~kg} \cdot \mathrm{m}^{-3}\right)$ for the panels, but do not vary more than $10 \%$ (ANSIA208.1, (CPA, 2009). This was attributed to the possible losses of materials during handling in the process of forming the panels in the laboratory, without the automation and precision control of the industrial process (Iwakiri et al., 2012).

The low compression tensions generated during the pressing process of the panels made with wood of higher basic densities is due to lower compression ratio. These panels release part of the compression tensions in a less accentuated way soon after the pressing process maintaining their thickness in near the planned nominal, as observed in the present study.

The panels produced, except those with Erisma uncinatum wood, conformed to the reference standard ANSI A208.1 that should be of a maximum of $10 \%$ for moisture content (CPA, 2009). The transformation of the wood in particles and the pressure and temperature conditions used in the pressing of the particulate mat reduces the hygroscopicity of the resulting panel and, consequently, its equilibrium moisture content will be lower than that of the solid wood used to produce it (Wu, 1999).

The water absorption is related to the panel and wood porosity with the liquid occupying the empty spaces between the particles and the wood cell interior (lumen) of the immersed panels, where it remains by the capillary force action. The lower Hymenolobium excelsum and Tachigali myrmecophyla wood basic densities increased the particle volume used to

Table 3 - Modulus of rupture (MoR) and modulus of elasticity (MoE) to static bending and internal bonding of particleboards. Tabela 3 - Módulo de ruptura (MoR) e de elasticidade (MoE) à flexão estática e ligação interna dos painéis.

\begin{tabular}{lccc}
\hline Species & MoR & MoE & Internal bonding \\
\cline { 2 - 4 } & & $1616.74 \pm 265.93 \mathrm{~b}$ & $0.87 \pm 0.13 \mathrm{bc}$ \\
Caryocar villosum & $9.39 \pm 0.88 \mathrm{c}$ & $1223.65 \pm 193.74 \mathrm{ab}$ & $1.41 \pm 0.21 \mathrm{~d}$ \\
Hymenolobium excelsum & $8.76 \pm 1.55 \mathrm{bc}$ & $1281.93 \pm 188.18 \mathrm{ab}$ & $0.45 \pm 0.04 \mathrm{a}$ \\
Mezilaurus itauba & $4.86 \pm 0.30 \mathrm{a}$ & $966.15 \pm 116.27 \mathrm{a}$ & $0.63 \pm 0.16 \mathrm{ab}$ \\
Erisma uncinatum & $5.22 \pm 1.18 \mathrm{a}$ & $1290.17 \pm 162.52 \mathrm{ab}$ & $1.18 \pm 0.08 \mathrm{~cd}$ \\
Tachigali myrmecophyla & $10.04 \pm 0.59 \mathrm{c}$ & $887.63 \pm 129.02 \mathrm{a}$ & $0.57 \pm 0.03 \mathrm{ab}$ \\
Qualea paraensis & $4.59 \pm 0.18 \mathrm{a}$ & $1124.05 \pm 92.30 \mathrm{a}$ & $0.71 \pm 0.03 \mathrm{ab}$ \\
Mixture & $6.33 \pm 0.64 \mathrm{ab}$ &
\end{tabular}

Means followed by the same letter per column do not differ by the Tukey test $(\alpha=0.05)$.

Revista Árvore. 2019;43(1):e430102 
manufacture the panels and therefore available voids (lumens) to be occupied by water. This cannot be applied to Erisma uncinatum wood with the lowest basic density and higher compression ratio and good performance for WA2h and WA24h, with the high panel densification probably crushed the cells and, consequently, reduced the lumen volume.

The water absorption by the panel immersed causes its swelling in thickness with two components for this variable, the wood intrinsic swelling and the release of the compression tensions on the panel during the pressing. Compression tensions developed during the panel production process are due to the particulatemat compacting and are retained in the consolidated panel by the adhesive bond action between the particles (Del Menezzi, 2004). Panels with the Tachigali myrmecophyla, Hymenolobium excelsum, Erisma uncinatum wood and mixture, with higher effective compression ratios, were those more probably to swell due to the release of the higher magnitude compression tensions.

The lowest values for the MoR and MoE properties for the Qualea paraensis residue panel indicate effect by the compression ratio. Panel with the same nominal apparent density, but produced with a higher basic density material, usually, has lower resistance to static bending due to its lower compression ratio (Kelly, 1977; Maloney, 1993). This applies to panels produced from the Mezilaurus itauba residues, but not for those made with Erisma uncinatum and residues and the wood mixture with compression ratio of 1.6 , which theoretically should have presented better MoR and MoE. This indicates the influence of the "fines" retained in the collector and the adhesive content applied for panels production, because panels with higher apparent density require a greater amount of adhesive due to the larger surface area of the particles (Marra, 1992). The increase in the apparent panel density resulted from the higher $\mathrm{MoE}$ and MoR mean values indicating the possibility of producing particleboards with specific mass above $800 \mathrm{~kg} . \mathrm{m}^{-3}$ for applications requiring high mechanical strength (Iwakiri et al., 2008).

The MoR of the panels produced were below those stipulated, but the panels with the Caryocar villosum, Hymenolobium excelsum and Tachigali myrmecophyla wood had values closer to the minimum required of 14.9 and $11 \mathrm{MPa}$ for the $\mathrm{H}-1$ and PBU classifications, respectively ANSI A208.1 (CPA, 2009). Panels of all treatments did not meet the requirements, of a minimum of 2160 and $1725 \mathrm{MPa}$ for the MoE in the H-1 and PBU classifications, respectively, but those of Caryocar villosum had average value closer to the established minimums.

The low resistance of the adhesive bond between the particles of the panels produced with Mezilaurus itauba and Qualea paraensis woods indicates that the extractives could have affected the polymerization and curing of the adhesive in the production. The low internal bonding values for the panels with Erisma uncinatum residues and mixture may be due to the higher relative volume of particles of the mat and to the lower adhesive availability per particle. This demonstrates the compression ratio influenced in this property. The improvement of this property could be obtained by increasing the adhesive content in the panel production (Bufalino et al., 2012).

The ANSI A208.1 standard (CPA, 2009) indicates a minimum value for the internal bonding property equal to $0.81 \mathrm{MPa}$ for the $\mathrm{H}-1$ classification and 0.40 for PBU. The panels produced with the woods of Caryocar villosum, Hymenolobium excelsum and Tachigali myrmecophyla had mean values of internal bonding above the minimum required by the reference standard for the H-1 classification. All the treatments were above of the stipulated for PBU classification and thus met the standard.

\section{CONCLUSION}

The particleboards produced with the Caryocar villosum, Hymenolobium excelsum and Tachigali myrmecophyla wood residues presented, in general, higher mechanical properties than Mezilaurus itauba, Erisma uncinatum, Qualea paraensis and the mixture. Those species met one or more minimum requirements of the ANSI standard A208.1 (2009) for highdensity panels (H-1 classification) and for those to produce floors (PBU classification).

\section{ACKNOWLEDGMENTS}

We would like to thank International Tropical Timber Organization (ITTO), Associação Nacional dos Produtores de Pisos de Madeira (ANPM) and Coordenação de Aperfeiçoamento de Pessoal de Nível Superior (CAPES).

\section{REFERENCES}

Associação Brasileira de Normas Técnicas ABNT. NBR 11941: madeira: determinação da

Revista Árvore. 2019;43(1):e430102 
densidade básica. Rio de Janeiro: ABNT; 2003.

Associação Brasileira de Normas Técnicas ABNT. NBR 14810-3: chapas de madeira aglomerada: métodos de ensaio. Rio de Janeiro: ABNT; 2006.

Bufalino L, Protásio TP, César AAS, Sá VA, Mendes LM. Modelagem de propriedades físicas e mecânicas em painéis aglomerados de cedro australiano. Floresta e Ambiente. 2012;19(2):243-9.

Composite Panel Association - CPA. ANSI A 208.1: particleboard standard. Leesburg: CPA; 2009.

Del Menezzi CHS. Estabilização dimensional por meio do tratamento térmico e seus efeitos sobre as propriedades de painéis de partículas orientadas (OSB) [tese]. Curitiba: Universidade Federal do Paraná; 2004.

International Tropical Timber Organization - ITTO. Biennial review and assessment of the world timber situation 2015-2016. Yokohama: ITTO, Division of Economic Information and Market Intelligence; 2016.

Iwakiri S, Andrade AS, Cardoso Junior AA, Chipanski ER, Prata JG, Adriazola MKO. Produção de painéis aglomerados de alta densificação com uso de resina melamina-uréia-formaldeído. Cerne. 2005;11(4):323-8.

Iwakiri S, Stinghen ABM, Silveira EL, Zamarian EHC, Prata JG, Bronoski M. Influência da massa específica sobre as propriedades mecânicas de painéis aglomerados. Floresta. 2008;38(3):487-93.

Iwakiri S, Zeller F, Pinto JA, Ramirez MGL, Souza MM, Seixas R. Avaliação do potencial de utilização da madeira de Schizolobium amazonicum "Paricá" e Cecropia hololeuca
"Embaúba" para produção de painéis aglomerados. Acta Amazonica. 2010;40(2):303-8.

Iwakiri S, Vianez BF, Weber C, Trianoski R, Almeida VC. Avaliação das propriedades de painéis aglomerados produzidos com resíduos de serrarias de nove espécies de madeiras tropicais da Amazônia. Acta Amazonica. 2012;42(1):59-64.

Kelly MW. A critical literature review of relationships between processing parameters and physical properties of particleboards. Madison: U.S. Forest Products Laboratory; 1977.

Maloney TM. Modern particleboard e dry-process fiberboard manufacturing. 2nd. ed. San Francisco: Miller Freeman; 1993.

Marra AA. Technology of wood bonding: principles in practice. New York: Van Nostrand Reinhold; 1992.

Melo JE, Coradin VTR, Mendes JC. Classes de densidade para madeiras da Amazônia brasileira. Silvicultura. 1992;12(42):695-9.

Melo LEL, Silva CJ, Lopes KV, Brito PGM, Santos, I.S. Resíduos de serraria no Estado do Pará: caracterização, quantificação e utilização adequada. Floresta e Ambiente. 2012;19(1):113-6.

Nolasco AM, Uliana L. Gerenciamento de resíduos na indústria de pisos de madeira. Piracicaba: ANPM; 2014.

Trianoski R, Iwakiri S, Nascimento CC, Bila NF. Painéis aglomerados produzidos com quatro espécies de madeiras tropicais da Amazônia. Scientia Forestalis. 2015;43(106):445-52.

Wu Q. Application of Nelson's sorption isotherm to wood composites and overlays. Wood and Fiber Science. 1999;31(2):187-91. 